\title{
CCND2 Positive
}

National Cancer Institute

\section{Source}

National Cancer Institute. CCND2 Positive. NCI Thesaurus. Code C141300.

An indication that CCND2 expression has been detected in a sample. 